\title{
ADVERTISING PRODUCT AS THE ACCOUNTING OBJECT: PROBLEMS OF IDENTIFICATION BY NATIONAL AND INTERNATIONAL STANDARDS
}

\section{РЕКЛАМНИЙ ПРОДУКТ ЯК ОБ'ЄКТ БУХГАЛТЕРСЬКОГО ОБЛІКУ: ПРОБЛЕМИ ІДЕНТИФІКАЦІЇ ЗА НАЦІОНАЛЬНИМИ ТА МІЖНАРОДНИМИ СТАНДАРТАМИ}

Alona V. Lysiuk, PhD in Economics, Associate Professor Kyiv Cooperative Institute of Business and Law, Kyiv, Ukraine

ORCID: 0000-0002-1336-2209

Email: Alena.lysjuk@gmail.com

Received 01.01.2020

Лисюк А.В. Рекламний продукт як об'єкт бухгалтерського обліку: проблеми ідентифікачї за начіональними та міжнародними стандартами. Науково-методична стаття.

Успішна діяльність будь-якого підприємства залежить від ефективного застосування рекламних стратегій і відповідного просування його готової продукції на ринки збуту. Проте, враховуючи нинішні тенденції розвитку економічних відносин, постає проблема забезпечення достовірною та адекватною інформацією щодо можливості використання таких засобів просування товарів i, відповідно, забезпечення конкурентоспроможності власної продукції, створення позитивного іміджу підприємству. Дослідження зосереджено на теоретичному обгрунтуванні та вирішенні ряду питань, пов'язаних з удосконаленням організації та методики обліку операцій 3 рекламним продуктом. Визначено економічну сутність рекламного продукту, а також визначено об єкти обліку з точки зору форм прояву рекламних продуктів

Ключові слова: рекламний продукт, реклама, система бухгалтерського обліку, національні та міжнародні стандарти

Lysiuk A.V. Advertising product as the accounting object: problems of identification by national and international standards. Scientific and methodical article

Successful business of any company depends on the effective use of advertising strategies and the corresponding promotion of its finished products onto the markets. However, given the current trends in the development of economic relations, there is a problem of providing reliable and adequate information on the possibility of using such means of product promotion and, accordingly, ensuring the competitiveness of its own products, creating a positive image for the company. The research focuses on the theoretical justification and solution of a number of issues related to the improvement of the organization and methods of accounting for transactions with advertising products. The economic nature of advertising product has been defined as well as the accounting objects in terms of emergence of advertising items have been identified.

Keywords: advertising product, advertising, accounting system, national and international standards

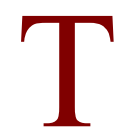

he use of marketing communications in business activities is an integral part of effective functioning and development of the enterprise. Understanding the essence of marketing in accordance with the development of modern economic relations is characterized as the target philosophy of enterprise management, focused on the consumer. In this context, advertising serves as one of the tools of marketing communications, that is a means to achieve the overall goal of marketing. Therefore, comparing the economic essence and meaning of the concepts of marketing and advertising in economic activities, it should be noted that marketing serves the purpose for the strategy of building a management system in the context of targeting the consumer, while advertising acts as a component of tactical actions to achieve a common strategy that determines the relevance of its research.

The development of the advertising market is confirmed by the statistics of the All-Ukrainian advertising coalition [1] that show "in 2019, the advertising and communication industry of Ukraine has shown remarkable growth" complications "in the political and economic life of our country has shifted from falling and stagnating to growth. According to the results of 2019, the media advertising market has grown by $25 \%$ (total advertising media market 24131 million UAH). 2020 forecasts the year of growth will remain, but the growth rate will slow down slightly up to $+18 \%$ [1]. According to the Statistics Portal [2], the spending on advertising worldwide has been increasing steadily and is expected to surpass 560 billion U.S. dollars in 2019.

\section{Analysis of recent researches and publications}

Recent research has shown that the advertising product is regarded as an expense, and, in turn, the recognition of the advertising product as an asset is slightly considered by scientists. 
The following national scientists have devoted their research to the issues of advertising management and accounting of the advertising product: O.S. Havrylovskyi (2014) [2], V.A. Derii $(2013,2015)$ [4, 5], I.V. Zholner (2010)[6], N.H. Zdyrko (2019) [7]; and foreign researchers: F. Jeffkins (2008) [8], F.Kotler, V.Wong, G.Armstrong, J. Saunders (2010) [9], N.V. Ivanova (2011) [10], M. Rogozhin (2010) [11] and other scholars.

\section{Unsolved aspects of the problem}

The rapid development of the advertising market in Ukraine and in the world, as well as the expansion of methods and methodology for placing advertising communications, requires a reliable reflection of operations of introduction and use of advertising communications in accounting.

The aim of the article is to investigate the economic essence of an advertising product to identify it as an object of accounting and specify the problematic aspects of accounting of transactions in compliance with the national and international standards.

\section{The main part}

Considering the influence of the use of promotional products on the business activities of the enterprise, understanding their economic essence acquires a new meaning in the modern economic system. With the development of new methods and methodology of using advertising products acquiring new functions and tasks, a significant impact on the competitiveness of both products and enterprises is changing the economic and social essence of advertising as a category (the content and form adapt to the development of production and changes in socio-economic formations).

The peculiarity of advertising is its wide understanding in accordance with the functions performed, which influences the interpretation of its essence by researchers. The conducted research allows grouping the interpretation of the concept of advertising into the following areas: target or special information; form of messages about goods (services); marketing component; purposeful influence; form of sales and promotion of goods. The trends determine the value of advertising for the enterprise's business. Yet they do not allow identifying objects of accounting for transactions with promotional products.

Studying the economic essence of advertising has shown that as a result of the development of socioeconomic relations, advertising has become a multifaceted category and it is realized from the following positions: 1) as a type of activity (process); 2) as a set of information flows; 3 ) as communication.

Advertising as a type of activity (process) is realized from two positions according to the subject of implementation, as shown in Fig. 1.

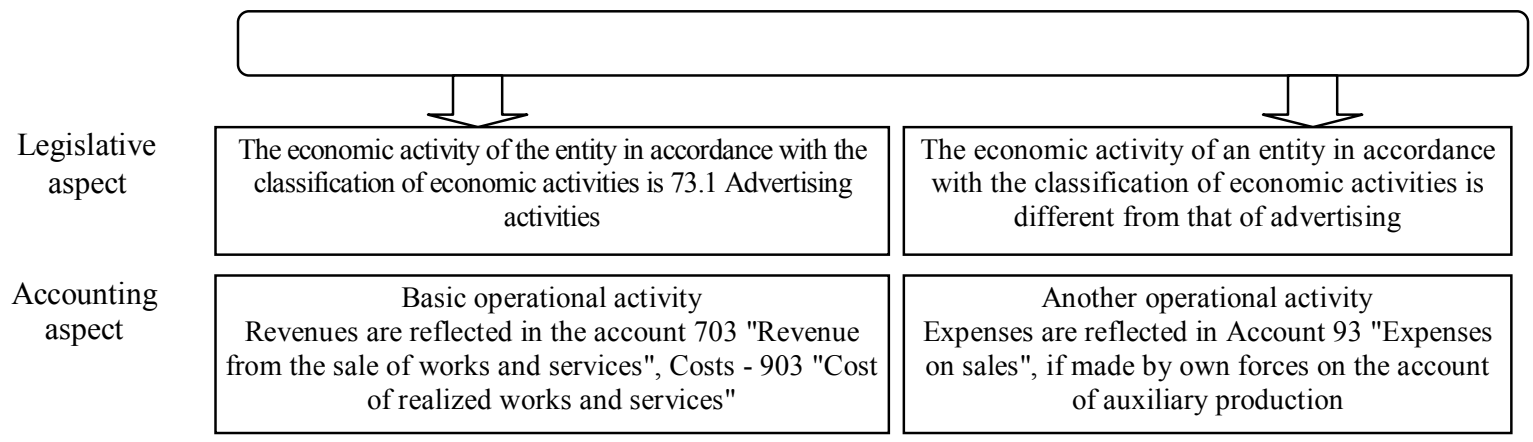

Figure 1. Recognition of advertising: legislative and accounting aspects Source: autor's own development

From the position of a business entity that uses marketing communications in its business activities in accordance with the general strategy for the development of an enterprise, there may be separate divisions. In this case, advertising acts as an integral part of the marketing system, which is implemented in practice in accordance with the general marketing strategy. The research uses the notion of the advertiser who uses means of advertising to position his own products or firms on the market to obtain an economic effect. Advertising as a type of activity is also considered from the position of the company, which provides advertising services in production and placement of advertising, since it is its main activity "advertising agency". If advertisement is already ready to be used and directed to the consumer, it acts as a message form and plays as an informational role.
At this stage, the value of advertising is implemented as a set of information flows, expressed in the form of the message about the object of advertising. The value of advertising as a set of information flows is realized in shaping the influence of the subject of economic activity on the consumer and providing feedback. Construction of an effective system of relationship "producer-consumer" allows implementing advertising as communication, ensuring establishment of relations between the subjects of advertising relations.

Advertising, as an economic phenomenon, acts in the form of information about the object of advertising, which might be in the form of various objects and phenomena. In order to bring this information to the consumer, it is necessary to use the medium of advertisement and the means of placing in accordance with the chosen type of advertising 
(advertising type). The set of all elements that allow advertising as information to bring to the consumer (information about the object of advertising, the carrier of advertising, the way of placing) forms an advertising product as a result of the advertising activity.

Consequently, advertising information cannot be an object of accounting, since it does not exist separately from the carrier of advertising, and it cannot be brought to the consumer without its placement. Therefore, the object of accounting is the economic operations carried out at each stage of the lifecycle of the promotional product.

In the implementation of advertising activities in accounting, there is a series of business operations with advertising products, which acquire tangible and intangible forms. Consequently, the advertising product is the result of the implementation of the advertising process, expressed in material or nonmaterial form, the cost of which can be reliably determined.

Figure 2 reflects the advertising process and the role of the advertising product in the relation to the essence of advertising, which allowed forming an approach to economic understanding of advertising, determining its impact on the micro, macro level and outlining the object of accounting in the implementation of advertising activities.

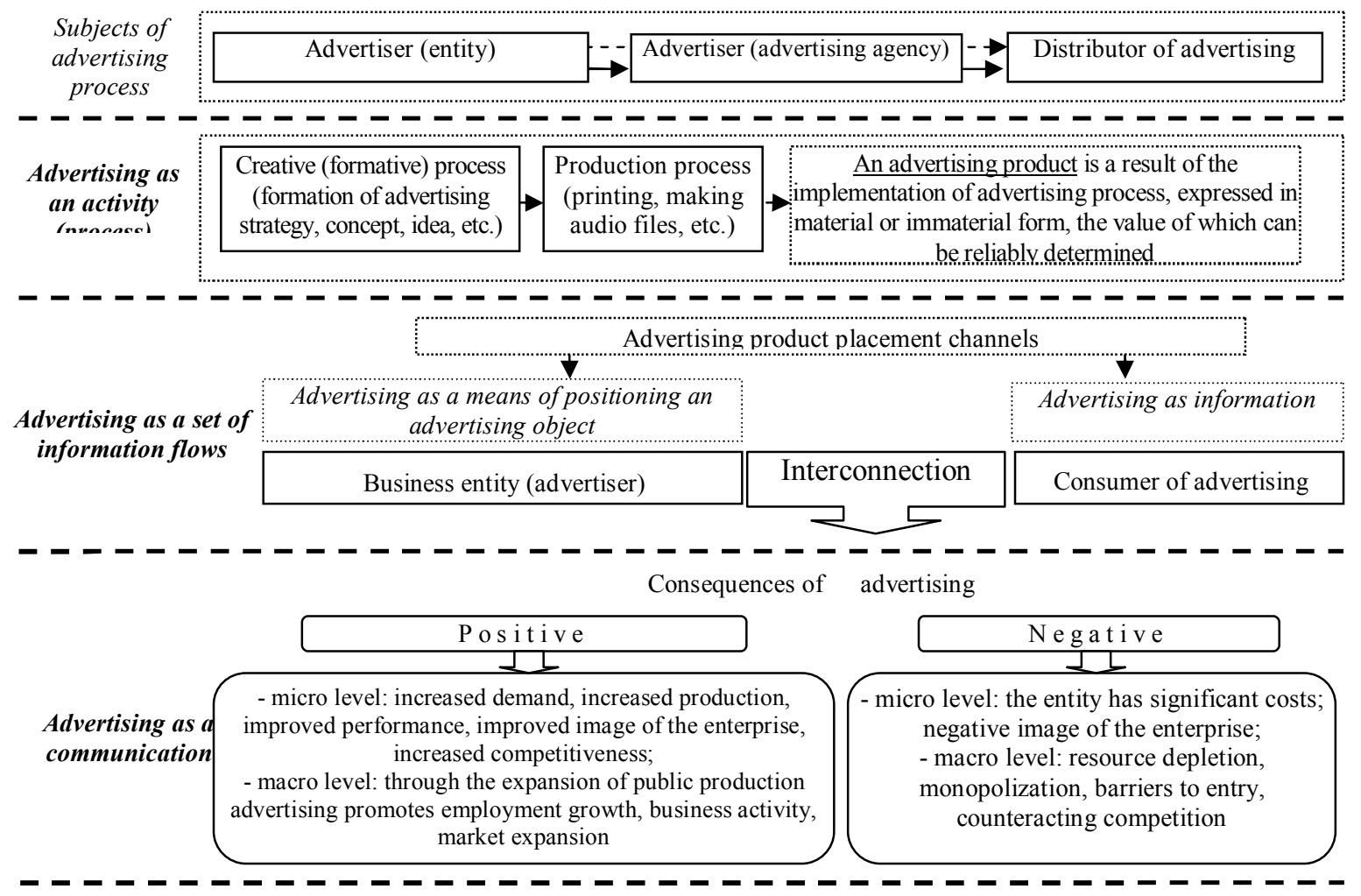

Figure 2. The essence of advertising: the identification of the advertising product as an object of accounting Source: autor's own development

Figure 1.3 illustrates the approaches to understanding the economic matter of advertising, which is, regarding the purposes of this study, a basis in the context of understanding the totality of economic transactions carried out by business entities in production or order (use) of promotional products.

The purpose of advertising in business is to meet public needs, which is implemented on the macro level. As a result of exposure to advertising, an entity receives positive or negative effects from its use, which is realized on the micro and macro levels. The effectiveness of advertising is characterized by indicators of economic activity of the enterprise, the analysis of which will allow to decide on the further use of advertising or a possible adjustment of its development strategy. This decision will have a direct impact on the volume and structure of the costs incurred. In this case, there is a feedback from advertising, as communication, to advertising as an activity, that is, depending on the result obtained, management personnel decides on the further use of advertising in business.

Analyzing the impact of advertising on the macro level, it is evident that it acquires social significance, that is manifested as a social category, but this is not the only case of such manifestation (social advertising, advertising as information affecting a citizen as a result of its review, etc.

In carrying out advertising activities, the object of accounting is operations with an advertising product, which manifests itself in different forms, depending on the method of distribution and the carrier of advertising (Fig. 3). 


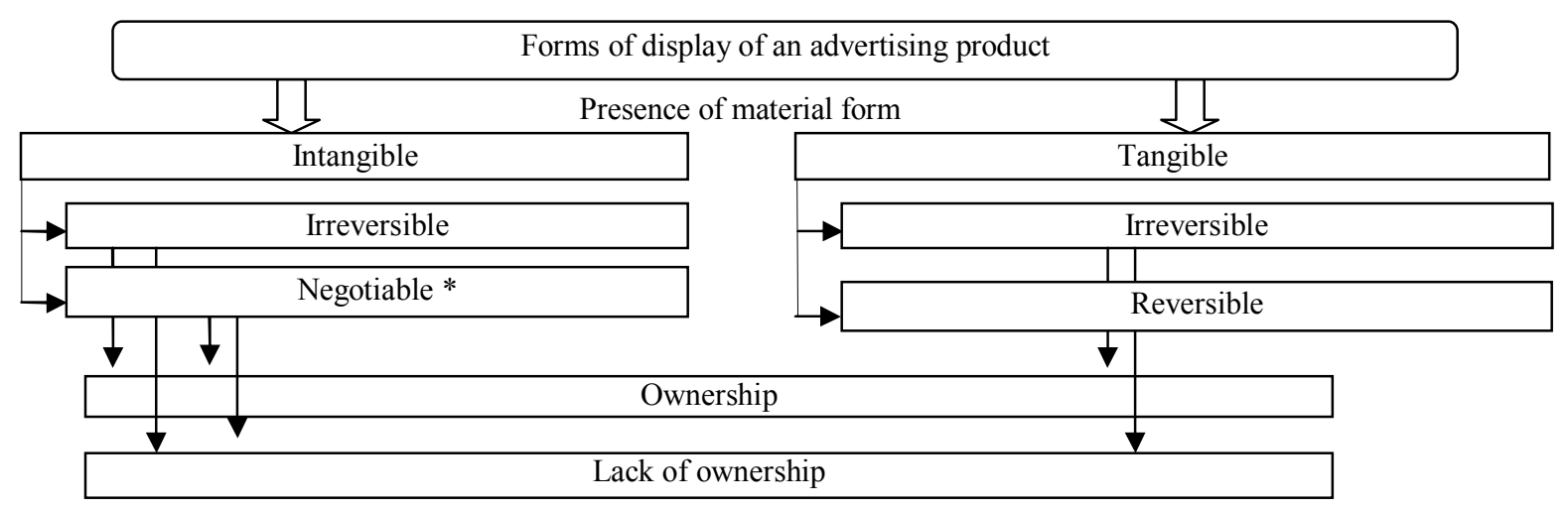

* Note: the problem aspect is not currently provided for in the accounts and there is no methodology for accounting to display of such operations with the right of ownership and without ownership

Figure 3. Forms of advertising product display: identification of objects of accounting Source: autor`s own development

Thus, forms of advertising product manifestation in advertising activity are realized in the objects of accounting accordingly to availability of tangible or intangible form and the availability of property rights of the entity for the product. However, as it is shown in Fig. 3, there is a problematic aspect when identifying accounting objects in terms of current assets with ownership. Since the current legislative framework has not regulated the issues reflected in the accounting of assets are intangible with the term used in business less than a year. The variants of forming operations with advertising products are possible based on the legal essence, but there are no instruments for their reflection in accounting.

Consequently, the disclosure of the forms of display of an advertising product in accordance with the existence of property rights showed the totality of economic transactions that arise in the implementation of advertising activities and outlined the problematic aspects of their accounting display, namely the lack of methodological provision of accounting for operations with intangible assets used for less than a year, to which the advertiser owns the property.

According to the current legislation of Ukraine, there is no normative regulation of operations with circulating intangible assets. According to the National provisions (standard) accounting 1 "General Requirements for Financial Statements" [12], assets are resources controlled by the enterprise as a result of past events, the use of which is expected to generate future economic benefits, while current assets are cash and cash equivalents that are not restricted in use, as well as other assets, intended for sale or consumption during the operating cycle or for a period of twelve months from the balance sheet date. The foregoing indicates the possibility of forming such an asset as a negotiable intangible asset, provided that it is a controlled enterprise as a result of past events and their use will bring future economic benefits.

Investigation of the provisions of the Conceptual Framework for the Compilation and Presentation of Financial Statements (The Conceptual Framework for Financial Reporting) [13] showed the possibility of forming such assets. This document specifies that assets (Assets) are resource controlled entities as a result of past events, which are expected flow of future economic benefits to the enterprise.

Holov S.F. and V.M. Kostiuchenko summarize the provisions of IFRS and determine that a resource is considered an asset if it meets the following three conditions:

- An enterprise has received it as a result of past transactions or events (acquisition, construction, etc.), since the intention of the enterprise to acquire, for example, stocks does not mean the availability of assets. In this case, the lack of material form and costs incurred is not an obstacle to assuming the asset received by the resource. For example, royalty-free copyrights can be its asset.

- It is controlled by the enterprise. Such control is derived from the ownership of assets or other legal rights (for example, the use of an asset under financial leasing terms), which allows an entity to control the future benefits that it expects to obtain from such an asset.

- It embraces future economic benefits[14, p. 39]

Future economic benefit is the potential ability of the asset to contribute (directly or indirectly) to the receipt of cash or cash equivalents at the enterprise [14, p. 39].

Paragraph 4.10 of the Conceptual Framework for the Formulation and Submission of Financial Statements [13] determines that future economic benefits embodied in the asset may flow to the entity in various ways. For example, you can:

- used separately or together with other assets in the production of goods or services provided for sale by an entity;

- exchange for other assets;

— use for debt repayment;

- distribute among the owners of the business entity.

Consequently, to assess the balance sheet as an asset or an obligation, it is necessary to draw attention to the economic substance, and not only to the legal form. 
IAS 1 [15] distinguishes between current and noncurrent assets. Paragraph 66 specifies that an entity should classify an asset as current if:

— it hopes to realize this asset or intends to sell or consume it in his normal operating cycle;

— it holds the asset primarily with the purpose of selling;

- it hopes to realize the asset within twelve months after the reporting period; or

- the asset is cash or cash equivalents (as defined in IAS 7 ), unless there are restrictions on the exchange or use of this asset to repay the liability for at least twelve months after the reporting period.

Consequently, on the basis of consideration of the Conceptual Framework for the Formulation and Submission of Financial Statements and IAS 1, it has been determined that, in accordance with the provisions of the aforementioned documents, advertising products in the form of the development of a negotiable intangible asset are recognized as current assets in the event that there is a controlled enterprise as a result of past events and it is expected that their use will bring future economic benefits to the enterprise.

The possibility of identification of negotiable intangible assets, as an object of accounting, identified O.L. Biliachenko [16] in the study of accounting and control of software operations, and proposed to display enterprise software by type of legal rights to it in account I Class "Non-current assets", as one of the types of intangible assets, and in account II class "Stocks", as one of the types of current assets. According to the results of research O.L. Biliachenko [16] determines that the software in the enterprise can be used for more than one year (long-term), such software (subject to recognition as an asset) refers to non-current intangible assets and in the account it is proposed to account 126 "Irreversible software"; and less than one year - current intangible asset, which is proposed to be reflected in the account 29 "Reversible software".

Implementation of advertising products in business activities is realized in the following objects of accounting (Fig. 4).

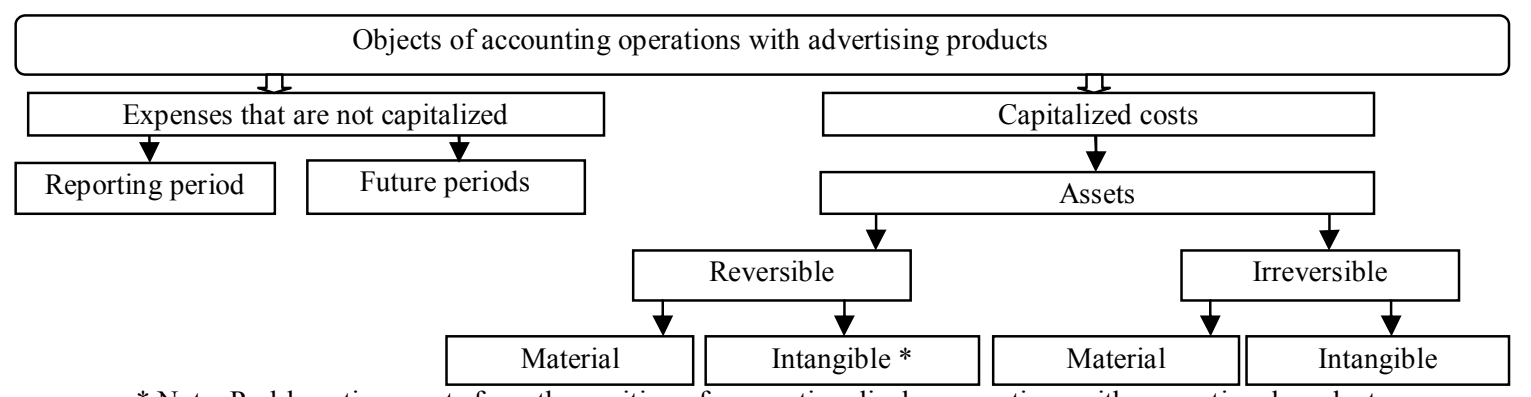

* Note: Problematic aspects from the position of accounting display operations with promotional products

Figure 4. Objects of accounting of transactions with advertising products from the advertiser Source: autor 's own development

Being used in business, advertising products can act as the following objects of accounting: the cost of the reporting period, costs of future periods, noncurrent and current assets in the context of the availability of material or immaterial form, which during the placement, exploitation of advertising carry its cost to the expenses of the reporting period.

\section{Conclusions}

As a result of the research, the place and role of the advertising product in the system of objects of accounting based on the prevailing socio-economic essence of advertising was substantiated. It is determined that an advertising product is a result of the implementation of the advertising process, expressed in material or immaterial form, the cost of which can be reliably determined.

In order to identify problem areas of accounting display of an advertising product from the advertiser and advertising agency, the influence of the forms of display of the advertising product on the objects of accounting is determined. In the accounting of an advertising agency, the production of an advertising product is reflected as production costs accumulating in the finished product. The advertiser identified objects of accounting operations with promotional products, which helps identify the totality of transactions arising in the business activities in the implementation of advertising activities (processes).

The study showed that according to the national legislation in force there is no methodical provision of accounting for operations with intangible assets used less than one year for which the advertiser owns the property. In the study of international standards, namely the Framework for the Preparation and Presentation of Financial Statements and IAS 1 stipulates that advertising products in the form of display working intangible asset recognized as current assets if there are controlled now as a result of past events and it is expected that their use will bring to in future economic benefits. 


\begin{abstract}
Introduction. The development of marketing communications, as a means of informatization of society, has led to the expansion of methods and ways for advertising placement, which requires effective management of their application in economic activities. The growth of the use of advertising products, as well as the emergence of new methods for their dissemination, leads to increased understanding of advertising in the modern economic system, which, through the prism of accounting, determines the problem of identifying accounting objects in order to accurately reflect them.

Purpose. The purpose of the article is to investigate the economic essence of an advertising product in order to identify it as an object of accounting and identify the problematic aspects of the accounting of such transactions in accordance with national and international standards.

Results. The author investigated and substantiated the economic essence of the category of "advertising", which is realized as activity (process), a set of information channels, communication. They determine the forms of manifestation of the advertising product in the accounting system (forms of advertising product manifestation are realized in the objects of accounting accordingly to availability of tangible or intangible form and the availability of property rights of the entity for the product), which affects the identification of operations that arise when using advertising. The authors provided a description of the possibility of identifying a negotiable intangible asset as an object of accounting in accordance with national and international standards.

Conclusions. Determining the economic essence of an advertising product and establishing the forms of its manifestation enabled to identify the objects of accounting for transactions with promotional products and to establish the problem of the lack of methodological provision of accounting for operations with intangible assets that are used less than a year, which will help improve the accounting system in accordance with modern methods of management.
\end{abstract}

\title{
Список літератури:
}

1. Advertising market [Електронний ресурс]. - Режим доступу: http://www.vrk.org.ua/adv/statistics

2. Global Advertising Market - Lists Statistics \& Facts [Електронний ресурс]. - Режим доступу: https://www.statista.com/topics/990/global-advertising-market/.

3. Гавриловський О.С. Сучасні підходи до вдосконалення обліку непрямих витрат на збут, рекламу й маркетинг // Науковий вісник Херсонського державного університету. Сер.: Економічні науки. 2014. Вип. 7(5). С. 118-120.

4. Дерій В.А. Відображення витрат на рекламу підприємства в системі обліку з позиції доцільності їхнього здійснення [Електронний ресурс] // Економіка: реалії часу. Науковий журнал. 2015. № 2 (18). C. 219-225. - Режим доступу до журн.: http://economics.opu.ua/files/archive/2015/n2.htm.

5. Дерій В.А. Витрати на збут у системі обліку й аналізу невиробничих витрат // Облік і фінанси. 2013. № 4(62). C. 20-23.

6. Жолнер І.В. Облік витрат на рекламу в контексті міжнародних та національних стандартів // Наукові праці Національного університету харчових технологій. 2010. № 35. С. 89-93.

7. Здирко Н.Г. Витрати на рекламу в соцмережах як об'єкт бухгалтерського обліку та оподаткування // Облік і фінанси, № 4 (86). 2019. С. 11-18.

8. Джефкінс Ф. Реклама. Advertising: практичний посібник/Френк Джефкінс; доповнення і ред. Д. Ядіна; пер. 44 англ. видання О. О. Чистякова. - Київ: Знання, 2008. 565 с.

9. Котлер Ф., Вонг В., Армстронг Г., Сондерс Дж. Основы маркетинга. - М.: Вильямс, 2010. 1200 с

10. Иванова Н.В. Развитие интегрированных маркетинговых коммуникаций // Вестник Алтайского государственного аграрного университета. 2011. Т. 84. № 10. С. 108-112.

11. Рогожин М.Ю. Теория и практика рекламной деятельности. М.: Алфа-пресс, 2010. 208 с.

12. Національне положення (стандарт) бухгалтерського обліку 1 “Загальні вимоги до фінансової звітності” [Електронний ресурс]. - Режим доступу: http://zakon4.rada.gov.ua/laws/show/z033613 page.

13. Концептуальна основа фінансової звітності [Електронний ресурс] - Режим доступу: http://zakon4.rada.gov.ua/laws/show/929_009.

14. Голов С.Ф., Костюченко В.М. Бухгалтерський облік та фінансова звітність за міжнародними стандартами. - [3-те вид., перероб. і доп.] - Х.: Фактор, 2013. 1072 с.

15. Міжнародний стандарт бухгалтерського обліку 1 "Подання фінансової звітності" [Електронний pecypc]. - Режим доступу: http://zakon4.rada.gov.ua/laws/show/929_013.

16. Біляченко О.Л. Бухгалтерський облік і контроль операцій з програмним забезпеченням: дис... канд. екон. наук: 08.00 .09 / О.Л. Біляченко. - Житомир, 2011. 362 с. 


\section{References:}

1. Advertising market. Retrieved from: http://www.vrk.org.ua/adv/statistics [in Ukrainian].

2. Global Advertising Market - Lists Statistics \& Facts. Retrieved from: https://www.statista.com/topics/990/global-advertising-market/ [in Ukrainian].

3. Havrylovskyi, O. S. (2014). Suchasni pidkhody do vdoskonalennia obliku nepriamykh vytrat na zbut, reklamu y marketynh [Modern approaches to improving the accounting of indirect costs for marketing, advertising and marketing]. Naukovyi visnyk Khersonskoho derzhavnoho universytetu. Ser.: Ekonomichni nauky, 7(5), 118-120 [in Ukrainian].

4. Derii, V.A. (2015). Vidobrazhennia vytrat na reklamu pidpryiemstva $\mathrm{v}$ systemi obliku $\mathrm{z}$ pozytsii dotsilnosti yikhnoho zdiisnennia [Display the cost of advertising the business in the accounting system from the point of view of their feasibility]. Ekonomika: realii chasu, (2), 219-225 [in Ukrainian].

5. Derii, V.A. (2013). Vytraty na zbut u systemi obliku y analizu nevyrobnychykh vytrat [Distribution Costs in Accounting and Analysis of Non-production-related Costs]. Oblik i finansy, 4(62), 20-23 [in Ukrainian].

6. Zholner, I.V. (2010). Oblik vytrat na reklamu v konteksti mizhnarodnykh ta natsionalnykh standartiv [Accounting for advertising costs in the context of international and national standards]. Naukovi pratsi Natsionalnoho universytetu kharchovykh tekhnolohii, (35), 89-93 [in Ukrainian].

7. Zdyrko, N.H. (2019). Vitrati na reklamu v soczmerezhakh yak ob'yekt bukhgalters'kogo obli 'ku ta opodatkuvannya [Expenditure on Advertising in Social Networks: Accounting and Taxation]. Oblik i finansy, 4 (86), 11-18 [in Ukrainian].

8. Jeffkins F. (2008)/ Reklama. Advertising: praktychnyy posibnyk / Frenk Dzhefkins; dopovnennya i red. D. Yadina; per. z 4 anhl. vydannya O. O. Chystyakova. - Kyyiv: Znannya, 2008. 565 [in Ukrainian].

9. Kotler Ph., Vong V., Armstrong G., Sonders J. Marketing essentials. - M: Williams, 2010. 1200 p [in Russian].

10. Ivanova N.V. Razvitie integrirovannyh marketingovyh kommunikacij [Development of integrated marketing communications]. Vestnik Altajskogo gosudarstvennogo agrarnogo universiteta, 2011, vol. 84, no. 10, pp. 108-112 [in Russian].

11. Rogozhin M.Yu. (2010) Teoriya i praktika reklamnoi deyatel'nosti [Theory and practice of advertising]. Moscow: Alfapress Publ [in Russian].

12. Regulation (standard) of accounting 1 "General Requirements for Financial Statements". Retrieved from: http://zakon4.rada.gov.ua/laws/show/z0336-13/page [in Ukrainian].

13. Financial reporting framework. Retrieved from: http://zakon4.rada.gov.ua/laws/show/929_009 [in Ukrainian].

14. Holov, S., \& Kostiuchenko, V. (2013). Bukhhalterskyi oblik i finansova zvitnist za mizhnarodnymy standartamy [Accounting and financial reporting according to international standards]. Kharkiv: Faktor [in Ukrainian].

15. International Accounting Standard 1 "Presentation of Financial Statements". Retrieved from: http://zakon4.rada.gov.ua/laws/show/929_013 [in Ukrainian].

16. Biliachenko O.L. Buhgalterskij oblik i kontrol operacij z programnim zabezpechennyam [Accounting and control operations software]: dis ... cand. econ. sciences: 08.00.09. Zhitomir, 2011. $362 \mathrm{p}$ [in Ukrainian].

\section{Посилання на статтю:}

Lysiuk A.V. Advertising product as the accounting object: problems of identification by national and international standards / A.V. Lysiuk // Економіка: реалії часу. Науковий журнал. - 2020. - № 2 (48). - C. 66-72. - Режим доступу до жсурн.: https://economics. opu.ua/files/archive/2020/No2/66.pdf.

DOI: 10.15276/ETR.02.2020.9. DOI: 10.5281/zenodo.3976893.

\section{Reference a Journal Article:}

Lysiuk A.V. Advertising product as the accounting object: problems of identification by national and international standards / A.V. Lysiuk // Economics: time realities. Scientific journal. - 2020. - № 2 (48). - P. 66-72. - Retrieved from https://economics.opu.ua/files/archive/2020/No2/66.pdf.

DOI: 10.15276/ETR.02.2020.9. DOI: 10.5281/zenodo.3976893. 